\title{
Effect of Golmus mosseae on various host to record colonization, spore production, soil $\mathrm{pH}$ and soil temperature
}

\author{
P.V. GAWANDE*, D.D. GULDEKAR AND P.S. MORE
}

Department of Plant Pathology, College of Agriculture (Dr.P.D.K.V.), NAGPUR (M.S.) INDIA

\author{
ARITCLE INFO \\ Received : 23.06 .2016 \\ Revised : 25.08 .2016 \\ Accepted : 09.09.2016

\section{KEY WORDS :} \\ Glomus mosseae, Guinea grass \\ (Panicum maximum), Para grass \\ (Urochloa mutica), Napier grass \\ (Pennisetum purpureum), Marvel \\ (Dichanthium annulatum), Wheat \\ (Triticum aestivum), Sorghum \\ (Sorghum bicolar), Maize (Zea mays \\ L.), Bajara (Pennisetum typhoideum), \\ Pea (Pisum sativum L.), colonization, \\ spore production, Soil $\mathrm{pH}$, Soil \\ temperature
}

*Corresponding author: Email : prem.nath27@yahoo.com

\begin{abstract}
Mycorrhizal fungi were species that intimately associate with plant roots forming a symbiotic relationship with the plants providing sugar for fungi and fungi providing nutrients such as phosphorus to the plants. Mycorrhizal fungi accumulate phosphate and transport large quantity of phosphate within their hyphae release to plant cell in root tissue. The present investigation entitled as effect of Glomus mosseae on various host to record colonization, spore production, soil $\mathrm{pH}$ and soil temperature was conducted at Plant Pathology Section, College of Agriculture, Nagpur, for mass multiplication of VAM ten different host was taken for study such as follows guinea grass (Panicum maximum), para grass (Urochloa mutica), napier grass (Pennisetum purpureum), marvel (Dichanthium annulatum), wheat (Triticum aestivum), sorghum (Sorghum bicolar L.), maize (Zea mays L.), bajara (Pennisetum typhoideum), pea (Pisum sativum L.), uninoculated control. Out of the ten host guinea grass (Panicum maximum) responded as most suitable host showing highest colonization 87.66 per cent and 420 spore production. It was observed that plants having higher AM colonization showed AM production showing a positive correlation. As time advances the intensity VAM colonization and spore production was increased upto 90 days. Soil $\mathrm{pH}$ and soil temperature did not change during investigation.
\end{abstract}

How to view point the article : Gawande, P.V., Guldekar, D.D. and More, P.S. (2016). Effect of Golmus mosseae on various host to record colonization, spore production, soil $\mathrm{pH}$ and soil temperature. Internat. J. Plant Protec., 9(2) : 498-503, DOI : 10.15740/HAS/IJPP/9.2/498-503. 